\title{
Resistance of Biomphalaria occidentalis from Varzea das Flores Dam, Minas Gerais, to Schistosoma mansoni Infection Detected by Low Stringency Polymerase Chain Reaction
}

\author{
Cecilia Pereira de Souza ${ }^{+}$, Liana K Jannotti Passos \\ Laboratório de Malacologia, Centro de Pesquisas René Rachou-Fiocruz, Av. Augusto de Lima 1715, 30190-002 \\ Belo Horizonte, MG, Brasil \\ Biomphalaria occidentalis Paraense, 1981 from Varzea das Flores dam, MG, Brazil, was exposed to \\ infection with Schistosoma mansoni. Individual infection was performed with $140 \mathrm{~B}$. occidentalis and \\ 100 B. glabrata snails using LE and SJ strains. Two groups of B. occidentalis were killed after seven \\ day-miracidia exposure to detect $\mathrm{S}$. mansoni DNA, through the low stringency polymerase chain reac- \\ tion (LS-PCR), and were negative. The infection rates were $69.2 \%$ (LE strain) and $96.7 \%$ (SJ strain) for \\ B. glabrata and $0 \%$ for $\mathrm{B}$. occidentalis. LS-PCR enabled early resistance diagnosis.
}

Key words: Schistosoma mansoni - Biomphalaria occidentalis - resistance - Minas Gerais

Among the ten mollusc species and one subspecies of the Biomphalaria genus (Pulmonata: Planorbidae), which are present in Brazil, three are recognized as Schistosoma mansoni intermediate hosts: B. glabrata, B. tenagophila and B. straminea. B. amazonica and B. peregrina are experimentally susceptible to the trematode (Corrêa \& Paraense 1971, Paraense 1973). Among the five resistant species to $S$. mansoni infection, it was included $B$. occidentalis Paraense, 1981, very similar to $B$. tenagophila by shell morphology.

B. occidentalis occurrence in Varzea das Flores dam has been recently reported (Lima et al. 1993). The Varzea das Flores dam, located in Contagem municipality, in Belo Horizonte microregion, MG, Brazil, is a leisure area used by bathers and for sporting competitions, mainly swimming tournaments. Malacological surveys were undertaken in the tributary streams and dam of this region in 1996 and 1997 by the Laboratório de Malacologia of Centro de Pesquisas René Rachou with the col-

Research supported by Fiocruz and Fundação Nacional da Saúde.

${ }^{+}$Corresponding author. Fax: +55-31-295.3115. E-mail: souzacp@cpqrr.fiocruz.br

Received 9 November 1999

Accepted 19 April 2000 laboration of the technicians from National Health Foundation. The study was performed to detect the presence of schistosomiasis vector molluscs in the dam region. The total of collected snails was: 180 specimens of B. glabrata, 35 of B. occidentalis, 17 of Melania tuberculata and 3 of Pomacea sp. The occurrence of these mollusc genus in Varzea das Flores dam was previously reported by Lima et al. (1993). Ten B. occidentalis snails, after the identification of the species (Paraense 1981), were placed into an aquarium for rearing. Afterwards, a hundred specimens, with 8-10 mm diameter, were individually exposed to 50 miracidia of the LE $S$. mansoni strain, from Belo Horizonte, MG and to 50 miracidia of the SJ strain, from São José dos Campos, SP, more adapted to B. tenagophila (Paraense \& Corrêa 1978). Simultaneously, two B. glabrata groups with 50 specimens each were individually exposed to 20 miracidia, of each strain, per mollusc.

After 30 days, the molluscs from each group were individually exposed to artificial light and examined under stereomicroscope, to detect snails which were shedding cercariae. They were then examined weekly until 52 days after exposure, when negative snails were submitted to squeezing. In June 1999, a new collect of B. occidentalis was undertaken in the same place, and after species identification they were placed into the aquarium for rearing. From the descendants, two groups of 20 specimens each, were individually exposed to 50 miracidia of the LE and SJ strains. After seven 
day-exposure to miracidia, snails were killed for detection of S. mansoni DNA through the low stringency polymerase chain reaction (LS-PCR), described by Dias Neto et al. (1993) and used for diagnosing $S$. mansoni infection in B. glabrata (Jannotti Passos et al. 1997). The results of the first and second experiments are shown in the Table and in the Figure. The gel was silver stained as described by Sanguinetti et al. (1994).

The miracidia of both $S$. mansoni strains penetrated in the snails of the two Biomphalaria species. B. glabrata were infected with both strains of the trematode, shedding cercariae (Table). $B$. occidentalis did not shed cercariae showing resistance to the infection with the trematode strains (Table). The parasite DNA profile was not detected in the molluscs after seven day-exposure (Figure). The characteristic S. mansoni DNA profile is observed by the presence of a band ladder separated by approximately $62 \mathrm{bp}$ (Figure). This pattern was just observed in the lanes two and three where $S$. mansoni DNA was present. In the lane three there is an infected B. glabrata and just $S$. mansoni DNA can be observed, as the primer was specifically designed for this trematode. In the lanes, where there was not $S$. mansoni DNA in the snails, a band complex was observed as the primers aligned less complementarily due to the low stringency alignment conditions of the reaction (Figure). The lack of parasite DNA indicates that although the miracidia had penetrated through the tentacles of the snails under the stereomicroscope, they did not develop and after seven days they had already been destroyed by the internal defence system of the mollusc.

These results are in accordance with those observed for B. occidentalis from ten localities in the states of Mato Grosso do Sul, Paraná and São Paulo

\section{TABLE}

Experimental infection of Biomphalaria occidentalis from Várzea das Flores dam, Contagem, MG, and $B$. glabrata group with two Schistosoma mansoni strains

\begin{tabular}{|c|c|c|c|c|c|c|}
\hline \multirow[b]{2}{*}{$\begin{array}{l}\text { Genus and } \\
\text { species }\end{array}$} & \multicolumn{5}{|c|}{ Mollusc } & \multirow[b]{2}{*}{$\begin{array}{l}\text { S. mansoni } \\
\text { strain }\end{array}$} \\
\hline & $\begin{array}{l}\text { Number } \\
\text { exposed }\end{array}$ & $\begin{array}{l}\text { Diameter } \\
(\mathrm{mm})\end{array}$ & $\begin{array}{c}\text { Number of } \\
\text { infected }\end{array}$ & $\begin{array}{l}\text { Infection } \\
\text { rate }(\%)^{a}\end{array}$ & $\begin{array}{l}\text { Mortality } \\
\text { rate }(\%)^{a}\end{array}$ & \\
\hline B. occidentalis & 50 & $8-10$ & 0 & 0 & 38 & LE \\
\hline B. glabrata & 50 & $8-10$ & 27 & 69.2 & 22 & LE \\
\hline B. occidentalis & 50 & $8-10$ & 0 & 0 & 32 & SJ \\
\hline B. glabrata & 50 & $8-10$ & 30 & 96.7 & 38 & SJ \\
\hline
\end{tabular}

$a$ : mortality and infection rates after 52 day-exposure to miracidia

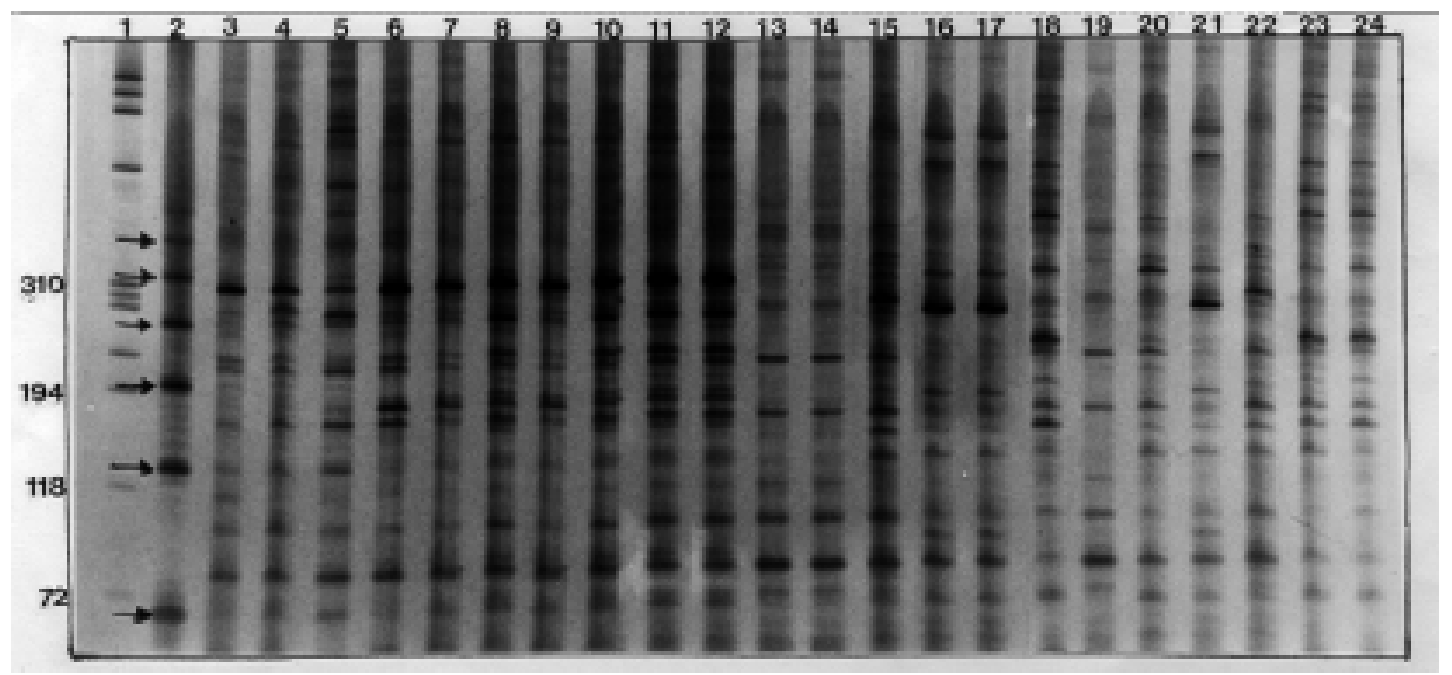

Silver stained $6 \%$ polyacrylamide gel showing low stringency polymerase chain reaction (LS-PCR) products obtained with specific primers ER(5'ACCTACCGTACTATGACG) and EF(5'GGTTTCTTAGTGTTATAGCC) for the mtDNA minisatellite and DNA. Lane 2: Schistosoma mansoni cercariae; lane 3: infected Biomphalaria glabrata; lanes 4 to 13: negative B. occidentalis seven days after $S$. mansoni exposure (strain LE); lanes 14 to 23: negative $B$. occidentalis seven days after $S$. mansoni exposure (strain SJ); lanes 24 and 25: negative B. occidentalis that were not exposed to S. mansoni. Lane 1: DNA size markers (f X174 restriction enzyme Hae III digestion) 
and also for specimens from Acre and Mato Grosso, which did not shed cercariae after experimental infection (Paraense \& Corrêa 1982, Coimbra Jr \& Engel 1982). All these populations showed to be resistant to infection with Brazilian S. mansoni strains. Hence, the LS-PCR technique performed parallelly to snails light exposure, have confirmed the resistance of $B$. occidentalis from Minas Gerais to two $S$. mansoni strains. This method showed that the parasite was destroyed at the first week after its penetration in the snail, enabling the early diagnose of the resistance.

\section{REFERENCES}

Coimbra Jr CEA, Engel LA 1982. Suscetibilidade de Biomphalaria occidentalis do Acre e Mato Grosso à infeção pelo Schistosoma mansoni e sua implicação na epidemiologia da esquistossomose na Amazônia Ocidental, Brasil. Acta Amazonica 12: 795-799.

Correa LR, Paraense WL 1971. Susceptibility of Biomphalaria amazonica to infection with two strains of Schistosoma mansoni. Rev Inst Med Trop São Paulo 13: 387-390.

Dias Neto E, Santos FR, Pena SDJ, Simpson AJG 1993. Sex determination by low stringency PCR (LS-PCR). Nucleic Acids Research 21: 763-764.
Jannotti Passos LK, Vidigal THDA, Dias Neto E, Pena SDJ, Simpson AJG, Dutra WO, Souza CP, Carvalho Parra JF 1997. PCR amplification of the mitochondrial DNA minisatellite region to detect Schistosoma mansoni infection in Biomphalaria glabrata snails. J Parasitol 83: 395-399.

Lima LC, Soares DM, Guimarães CT 1993. Biomphalaria occidentalis Paraense, 1981 in the state of Minas Gerais, Brazil. Mem Inst Oswaldo Cruz 88: 289-292.

Paraense WL 1973. Susceptibility of Biomphalaria peregrina from Brazil and Ecuador to two strains of Schistosoma mansoni. Rev Inst Med Trop São Paulo 15: $127-130$.

Paraense WL 1981. Biomphalaria occidentalis sp.n. from South America (Mollusca Basommatophora Pulmonata). Mem Inst Oswaldo Cruz 76: 199-211.

Paraense WL, Correa LR 1978. Differencial susceptibility of Biomphalaria tenagophila populations to infection with a strain of Schistosoma mansoni. $J$ Parasitol 64: 822-826.

Paraense, WL, Correa LR 1982. Unsusceptibility of Biomphalaria occidentalis to infection with a strain of Schistosoma mansoni. Mem Inst Oswaldo Cruz 77: 55-58.

Sanguinetti CJ, Neto ED, Simpson AJG 1994. Rapid silver staining and recovery of PCR products separated on polyacrylamide gels. Biotechniques 17: 915-917. 